\title{
Sikap Hormat Anak Terhadap Orang Tua Berdasarkan Prinsip Alkitab
}

\author{
Yanto Paulus Hermanto, Christine, Guntur Hari Mukti, Christopher Santoso, \\ Yonas Pasiran Ady Prayitno \\ Sekolah Tinggi Teologi Kharisma Bandung \\ Email: yantopaulush@gmail.com
}

\begin{abstract}
Honoring parents is a commandment from God that all mankind must carry out. This study aims to determine the true meaning of honouring parents and what practical action looks like. To answer the formulation of this problem, the researchers used a research method with a qualitative approach, namely, a method that looks for a deep meaning about the text, and extracts from several books or journals related to the problem. From the results of the discussion, honour for parents is an attitude that must be carried out throughout life through obedience, not insulting or criticizing and don't say harshly, as well as an attitude that nurtures, cares for and meets their needs. And God's promise for those who keep this law is a long life, happiness and a good condition, namely prosperity physically and spiritually.
\end{abstract}

Keywords: honour, obedient, nurture, parents, blessings

\begin{abstract}
ABSTRAK: Menghormati orang tua adalah perintah Tuhan yang harus dilaksanakan oleh semua umat manusia. Penelitian ini bertujuan untuk mengetahui arti yang sebenarnya secara biblika dari menghormati orang tua dan seperti apa tindakan praktisnya. Untuk menjawab rumusan masalah ini, maka peneliti melakukan penelitian dengan pendekatan kualitatif yaitu, metode yang mencari arti yang mendalam tentang teks, dan menggali dari beberapa buku atau jurnal yang berkaitan dengan masalah tersebut. Dari hasil pembahasan maka menghormati orang tua merupakan sikap yang harus dilakukan sepanjang umur hidup melalui sikap taat, tidak menghina atau mencela dan tidak berkata kasar, juga sikap yang memelihara, merawat dan mencukupi kebutuhan mereka. Dan janji Tuhan bagi orang yang melaksanakan hukum ini adalah panjang umur, kebahagiaan dan memiliki keadaan baik yakni kemakmuran secara jasmani dan rohani.
\end{abstract}

Kata kunci: Hormat, taat, memelihara, orang tua, berkat

Article History: Submitted: 06 Oktober 2020

Revised: 20 Januari 2021

Published: 30 Januari 2021

\section{PENDAHULUAN}

Keberhasilan dalam hidup adalah dambaan setiap orang, baik orang yang mapan dalam ekonomi, mempunyai keluarga harmonis, kuat secara rohani, maupun berhasil dalam kehidupan kini dan kehidupan yang akan datang. Seperti yang dikatakan Collier bahwa setiap orang menghendaki kesuksesan dalam hidupnya, keberhasilan dalam segala bidang termasuk dalam bidang ekonomi. Setiap orang menginginkan kesenangan, kenyamanan, kesehatan, kekuasaan dan kebahagiaan (Collier, 2018).

Bagi umat Tuhan yang mengasihi-Nya, Tuhan berjanji akan memberkati anak-anak-Nya. Sebagaimana yang dijanjikan-Nya kepada Abraham, bahwa melalui keturunannya semua bangsa akan mendapat berkat. Meskipun janji ini tidak secara langsung digenapi pada jaman Abraham, namun janji ini digenapi oleh keturunannya, yakni Yesus Kristus. Melalui-Nya semua bangsa diberkati. Se-mua orang akan mendapatkan beberapa berkat dari-Nya, dan sebagian orang akan mendapatkan semua berkat-Nya (Henry, n.d.).

Hidup anak Tuhan akan diberkati sesuai dengan janji-Nya kepada Abraham, janji itu digenapi dalam Yesus dan tetap berlaku sampai sekarang. Yang harus dilakukan anak Tuhan agar janji itu digenapi dalam hidupnya adalah; Satu, rajin bekerja (F. Simanjuntak, 2019). Dua, pelajari firman Tuhan. 
Tiga, lakukan firman Tuhan (Basuki, 2014). Ketiga hal ini harus dilakukan dengan setia dan dengan sikap mengasihi Tuhan dan sesama. Leks mengata-kan bahwa para rabi Yahudi membenarkan bahwa penting sekali mempelajari Taurat, tetapi lebih pen-ting lagi jika orang tersebut melakukannya. Injil ber-bicara bukan hanya tentang mendengar dan mempe-lajari sabda Yesus akan tetapi harus dilaksanakan se-cara nyata (Leks, 2012).

Salah satu janji Tuhan tentang memiliki keadaan baik dan berbahagia tertuang dalam beberapa ayat di Perjanjian Lama dan Perjanjian Baru. Dalam Keluaran 20:12, TUHAN memiliki tujuan yang mulia dengan memberi perintah kepada orang Israel untuk menghormati orang tua. Tujuannya adalah supaya mereka lanjut umur di tanah yang diberikan kepada mereka. Dalam Ulangan 5:16 tujuan TUHAN bukan saja lanjut umur, tapi juga memiliki keadaan yang baik (Mary, 2020). Hal ini dipertegas dalam Perjanjian Baru bahwa tujuan Tuhan memerintah umat-Nya dalam menghormati orang tua adalah supaya mereka lanjut umur dan berbahagia (Ef. 6:2-3). Perintah menghormati orang tua wajib dilakukan oleh umat-Nya. Menghormati orang tua adalah hu-kum Allah dari zaman ke zaman yang wajib dilaku-kan oleh umat manusia. Hukum ini penting, karena memiliki sebuah janji. Henry (n.d.) mengungkapkan bahwa kemakmuran lahiriah dan umur panjang adalah berkat-berkat yang dijanjikan kepada orang-orang yang menaati hukum ini.

Berkaitan dengan uraian pendahuluan ini maka masalah penelitian dalam jurnal ini adalah bagaimana sikap hormat anak terhadap orang tua berdasarkan Alkitab? Tindakan praktis apa yang dapat dilakukan sebagai sikap menghormati orang tua? Berbeda dengan peneliti sebelumnya yang hanya fokus pada bagaimana orang tua mendidik anak, dan bagaimana hubungan orang tua dan anak (Sulistiana, 2018), serta bagaimana makna menghormati orang tua dan menghormati orang yang lebih tua (Wardani \& Uyun, 2017). Jadi karya tulis ilmiah ini berbeda dengan penelitian-penelitian sebelumnya. Dengan demikian penulis berharap hasil penelitian ini dapat dijadikan bahan pembelajaran dalam pembinaan warga jemaat di berbagai gereja.

\section{METODE}

Untuk menjawab masalah di atas, maka peneliti melakukan penelitian dengan pendekatan kualitatif. Mengumpulkan semua buku dan jurnal yang membahas mengenai menghormati orang tua, sehingga diharapkan dapat menemukan jawaban yang tepat dan benar sesuai dengan maksud dari firman Tuhan. Baik tentang pengertian menghormati orang tua maupun tindakan-tindakan praktis yang menunjukkan pengertian tersebut. Adapun manfaat penelitian ini untuk memberikan pemahaman berdasarkan data, supaya anak-anak Tuhan dapat memahami arti "menghormati orang tua" dan menerapkan dalam kehidupannya. Dan kegunaan dari penelitian ini terdiri dari dua, yaitu: dari sisi teoritis akan memberikan pemahaman yang akurat dan teruji secara teologis mengenai "Menghormati orang tua". Sedangkan, dari sisi praktis, melalui penulisan karya ilmiah ini, "sikap menghormati orang tua" diharapkan menjadi masukan yang berguna bagi orang percaya, yaitu bahwa jika seorang anak menghormati orang tuanya dengan cara yang benar maka ia akan me-nerima janji Tuhan yaitu lanjut usia dan baik keada-annya (berbahagia).

Alkitab merupakan sumber utama dalam karya tulis ilmiah ini, sehingga arti sesungguhnya dari menghormati orang tua benar-benar diperoleh dari penggalian firman Allah, baik melalui tafsiran Alkitab maupun hasil dari para peneliti sebelumnya. Dengan demikian akan diperoleh gambaran yang jelas dan utuh terkait jawaban atas rumusan masalah dalam penelitian ini.

\section{HASIL DAN PEMBAHASAN}

Keluarga merupakan unit terkecil dalam masyarakat yang secara umum keluarga terdiri atas ayah, ibu dan anak, yang tinggal dalam satu rumah. Mereka menjalin komunikasi satu dengan yang lain dengan kebiasaan yang sudah tertanam lama (Putri, 2017). 


\section{Orang Tua Berdasar Alkitab}

Prince menjelaskan bahwa, bersatunya dua orang yang berlawanan jenis dalam suatu pernikahan akan membentuk sebuah keluarga. Dan pada akhirnya mereka menjadi orang tua yang memiliki anakanak (Prince, n.d.). Perkawinan ini tentunya merupakan ide Tuhan. Semua peraturan perkawinan termasuk tujuan akhirnya ditentukan oleh Dia. Dengan perkawinan, Tuhan mengadakan penyatuan antara satu laki-laki dan satu perempuan. Tetapi Alkitab melandaskan bahwa hanya ada satu landasan untuk penyatuan yang benar antara manusia, laki-laki dan perempuan yakni kasih. Alkitab menggambarkan perkawinan sebagai bersatunya dua orang (satu lakilaki dan satu perempuan) dengan meninggalkan kedua orang tua mereka (Kej. 2:24). Jadi kunci perkawinan adalah dua kata: meninggalkan dan bersatu. Kesatuan sejati antara seorang laki-laki dengan istrinya disebut keluarga utuh dalam lingkup perjanjian yang telah ditetapkan Tuhan. Ketika mereka diberi karunia memperoleh keturunan, mereka inilah yang dipercaya Tuhan untuk mendidik dan merawat anak tersebut dari sejak kandungan hingga besar dan mandiri (Prince, n.d.).

Anak yang ditempatkan dalam sebuah keluarga harus dirawat, dididik dan diajar, karena anak yang masih kecil belum mengerti hal yang baik dan tidak. Dengan berjalannya waktu, anak mulai berkembang dan bisa memahami tentang konsep baik dan buruk, benar dan salah, melalui lingkungannya. Agar anak mempunyai tingkah laku yang baik, anak perlu diberikan adanya suatu petunjuk atau ajaran. Menurut Eliman petunjuk atau ajaran merupakan pemberian bantuan oleh seseorang kepada orang lain dalam menentukan pilihan, penyesuaian dan pemecahan permasalahan. Petunjuk dan ajaran ini bertujuan membantu si penerima agar bertambah kemampuan bertanggung jawab atas dirinya (Eliman, 2017). Ajaran ini berupa didikan. Pendidikan dalam keluarga memiliki pengaruh yang kuat dalam membentuk emosi, sikap, dan perilaku. Kehidupan dalam keluarga merupakan tempat pertama kali bagi anak dalam mempelajari emosi, baik berupa mengenal emosi, merasakannya, menanggapi setiap situasi yang menyebabkan perubahan emosi serta mengungkapkan emosi. Melalui wadah pendidikan dalam keluarga, anak belajar mengungkapkan emosinya (Tafonao, 2019). Dalam Alkitab Penuntun Hidup Berkelimpahan dituliskan beberapa tugas orang tua untuk mengajar anaknya menuju kehidupan yang saleh di dalam Kristus, yakni: anak-anak diajar agar takut akan Tuhan; anak-anak diajar untuk menaati orang tua; anak-anak dilindungi dari berbagai pengaruh jahat; anak-anak disadarkan bahwa Allah selalu melihat setiap orang yang berbuat baik maupun jahat; anak-anak diajar pula bahwa Allah mengasihi setiap orang (Setiati, 2019; Stamps, 1984).

Dalam Kitab Ulangan bangsa Israel diingatkan bahwa mereka sebagai orang tua harus mengajarkan kepada anak-anak mereka mengenai siapakah Allah Israel. Setiap anak dari bangsa Israel harus mengenal siapa Allah dan bagaimana Ia berkarya dalam kehidupan nenek moyangnya. Pengenalan itu dilakukan melalui pengajaran firman Tuhan yang terus menerus. Naiboho menyatakan bahwa mengajarkan firman Tuhan adalah cara mendidik anak-anak mereka dengan tujuan, meneruskan iman yang dinamis dan transformasi (Naibaho, 2018).

Berdasarkan uraian di atas, maka tidaklah berlebihan, jika Allah sangat menghargai mereka (orang tua), sehingga setiap anak diperintahkan untuk menghormatinya, dan menjadi salah satu dari dasa titah yang diberikan Allah bagi orang Israel dan sekarang bagi seluruh anak Tuhan di seluruh dunia (Prince, n.d.).

\section{Anak Berdasar Alkitab}

Alkitab menuliskan bahwa anak adalah pemberian dari Allah bagi suatu keluarga. Sesungguhnya, anak-anak lelaki adalah milik pusaka dari pada TUHAN, dan buah kandungan adalah suatu upah (Maz. 127:3) (LAI, 2014). Sedangkan menurut Edwin Charis, anak itu ciptaan yang ajaib, ia memi-liki hidup kerohanian dan kejasmanian, dilengkapi dengan potensi untuk berkreasi, memiliki akal budi dan kehendak bebas, agar menjadi pribadi seperti yang 
Allah kehendaki (Charis, 2016). Pendapat dari Nggebu, Tuhan Allah memandang anak begitu penting bagi keluarga Kerajaan Allah. Mereka dipandang berharga di mata Tuhan. Anak-anak sederajat dengan orang dewasa dalam eksistensi dan kepribadian. Anak-anak memiliki kebutuhan dasar sama seperti orang dewasa. Allah mengasihi mereka sama seperti Dia mengasihi orang tua mereka. Dan Allah memanggil mereka untuk datang kepada-Nya sama seperti Dia memanggil orang-orang dewasa untuk menyerahkan hidup kepada-Nya (Nggebu, 2016).

Karena Ia mengasihi anak yang diciptakanNya, tentu saja Ia menempatkan anak tersebut dalam suatu keluarga yang di dalamnya bisa terdiri dari ayah, ibu, kakak dan adik, sehingga anak yang merupakan ciptaan-Nya mempunyai orang yang menyanyangi dan mengurusnya. Oleh sebab itu, seorang anak haruslah menghormati orang tuanya, seperti ia menghormati Allah. Karena tidaklah kebetulan seorang anak ada dalam satu keluarga, kalau bukan Tuhan yang menetapkannya (Frances, 2007).

\section{Menghormati Orang Tua}

Kata hormatilah dalam Keluaran 20:12 dan Ulangan 5:16 merupakan kata kerja. Penulisan dalam bahasa Ibrani: (kab·bêd lah, hormatilah, tunjukkanlah hormatmu. Sedangkan kata "Hormatilah" dalam Efesus 6:2, penulisan dalam bahasa Yunani; $\imath \mu \alpha \dot{\alpha}$ (Tima). Artinya menghormati, menghargai, memuliakan. Baik dalam Perjanjian Lama maupun Perjanjian Baru, menghormati ayah ibu bukanlah berdasarkan kesepakatan antara orang tua dan anak tetapi merupakan hukum dari Tuhan yang wajib dilakukan oleh setiap anak (Henry, n.d.).

Para teolog setuju kalau seorang anak harus bersikap hormat kepada orang tuanya, sehingga mereka menuliskan pendapat mereka tentang hormat kepada orang tua dari berbagai sudut pandang. Ada teolog yang mengatakan bahwa hormat pada ayah ibu adalah salah satu sikap yang penting (Runturambi, 2019). Paterson menegaskan, jika keempat hukum yang pertama mengenai kewajiban orang Israel ter- hadap Allah, maka hukum kelima dan seterusnya merupakan kewajiban orang Israel terhadap sesamanya. Yang pertama dari hukum kepada sesama adalah perintah untuk hormat pada orang tua sebagai sesama yang terdekat. Menurutnya tujuan pokok dari hukum ini adalah bukan hanya mengajar anak-anak kecil ataupun anak-anak muda tentang sikap mereka terhadap orang tua mereka, tetapi juga mengajarkan anak-anak dewasa bagaimana bersikap terhadap orang tua mereka yang telah berusia lanjut (Peterson, 2006).

Tuhan menurunkan hukum kelima dari dasa titah memiliki tujuan, yakni: Pertama, agar anak mengenal Allah. Banyak orang mengakui bahwa ada "semacam Allah" atau "semacam kekuatan" di balik alam semesta ini, tetapi mereka sama sekali buta tentang bagaimana caranya mengenal Allah. Banyak orang mungkin menyatakan bahwa mereka percaya Allah itu ada, akan tetapi berdasarkan perilaku hidup mereka sehari-hari, Allah yang penuh kasih itu tidak tercermin dalam tingkah laku mereka (Ridenour, 2000). Berdasarkan fakta tersebut, agar Allah yang penuh kasih dapat tercermin dalam tingkah laku mereka, maka dalam kehidupan sehari-hari orang tua harus menjadi gambaran Allah. Seperti yang ditulis oleh Dobson dalam bukunya Masalah Membesarkan Anak. Dia menyatakan bahwa seorang anak akan memiliki kecendrungan memandang orang tuanya sebagai gambaran Allah, apakah orang tua itu menghendakinya atau tidak. Contohnya, jika orang tua dalam satu keluarga penuh kasih, maka anak-anak itu akan belajar tentang kasih. Orang tua bertang-gung jawab penuh untuk mencerminkan kasih Allah kepada anak-anaknya. Bapa sorgawi adalah Allah yang penuh kasih dan kasih-Nya itu berlimpah dan tanpa batas. Oleh sebab itu anak-anak harus mengenal kasih dan kelembutan Allah melalui sikap orang tuaya yang penuh kasih juga (Dobson, n.d.).

Kedua, Agar anak memahami maksud Allah. Maksud Allah mengenai hormat kepada orang tua ialah Allah ingin supaya orang memelihara yang ditetapkan-Nya, maka tingkat-tingkat keutamaan yang ditentukan oleh-Nya tidak boleh di ganggu gu- 
gat. Artinya anak harus menganggap tinggi mereka yang ditempatkan Tuhan yaitu orang tua, bersikap hormat, dan taat kepada mereka (Calvin, 2000). Sehingga tidak boleh ada keraguan bahwa Allah telah menetapkan suatu peraturan yang umum siapapun yang diketahui ditempatkan Tuhan di atas kita yaitu orang tua, harus disegani dan ditaati, dan kepadanya harus berterima kasih, serta kita berikan segala macam pelayanan. Layak atau tidaknya orang tua menerima kehormatan, itu tidaklah menjadi soal, sebab bagaimanapun sifat mereka, tempat itu diperolehnya dari Allah. Hal inilah yang menjadi sebab Sang Pemberi Hukum sendiri menghendaki supaya mereka dihormati (Calvin, 2000). Stott mengatakan bahwa penghormatan kepada orang tua merupakan kewajiban manusia kepada Allah. Selama masa kanak-kanak orang tualah yang menjadi wakil Allah. Merekalah yang menyatakan kasih-Nya. Dengan demikian sikap hormat terhadap orang tua menjadi bagian integral dari sikap hormat terhadap Allah (Stott, 1986). Selanjutnya Sulistiana menegaskan bahwa penghormatan yang dimaksud mengandung aspek takut dan gentar, bukan takut seperti seorang hamba atau budak kepada tuannya, tetapi takut yang lahir dari kekaguman dan hormat seperti kepada Tuhan. Orang tua berhak atas penghormatan yang demikian (Sulistiana, 2018).

Ketiga, Kewajiban anak-anak yang paling besar adalah mentaati orang tua mereka (Henry, n.d.). Paulus memberikan alasan mengapa anak-anak wajib menaati orang tuanya, yakni kewajaran secara alamiah dan firman Tuhan (Sulistiana, 2018, p. 74). Perintah bahwa anak-anak wajib menaati orang tua tidak tergantung pada penyataan khusus dari Allah, melainkan pada "hukum wajar" yang dituliskan Allah pada hati nurani semua manusia. Hukum itu berlaku pada setiap masyarakat, bukan hanya pada masyarakat Kristen. Para pemikir moralis Yunani dan Romawi memang mengajarkan juga demikian. Dan menurut para filsuf Stott, bahwa seorang anak wajib mentaati orang tuanya tak usah dipersoalkan, karena menaati orang tua adalah tuntutan akal sehat (Stott, 1986). Alasan kedua adalah perkataan firman Tuhan yang berkata, "hai anak-anak taatilah orang tuamu di dalam Tuhan". Perintah ini mengartikan ketaatan anak adalah kewajiban kristiani, sebab yang disebut anak-anak di sini adalah anak-anak yang me-ngenal Tuhan Yesus Kristus. Kristus sebagai Pencipta, pada permulaan menetapkan aturan keluarga dan masyarakat dan Ia tetap setia pada aturan itu. Ada kesinambungan antara tatanan ciptaan lama dan tatanan ciptaan baru dalam Kristus. Lembaga keluarga tidak dihapuskan, selama manusia masih berkeluarga dan memiliki keturunan, anak-anak diminta untuk taat tidak hanya karena hal tersebut adalah komitmen kristiani, akan tetapi didasarkan atas kebenaran firman Allah (Stott, 1986).

Oleh Sebab itu perlu tindakan praktis yang dapat dilakukan anak sebagai wujud dari menghormati orang tua. Pertama, taat. Anak belajar taat kepada otoritas di atasnya yang dimulai dari rumah, yaitu orang tuanya. Seperti yang dikatakan Simanjuntak, konselor Keluarga dan Karier:

Allah sudah menentukan urutan otoritas dalam keluarga walaupun kita tidak suka: orang tua adalah pemimpin. Ayah adalah pemimpin atas seluruh keluarga. Anak-anak adalah pengikut orang tua. Kalau anak tidak belajar taat dalam rumah tangga, dia tidak akan taat di sekolah, dan tidak akan taat di tengah-tengah masya-rakat, begitu juga tidak akan taat kepada Tuhan. (J. Simanjuntak, 2017).

Namun demikian anak harus mentaati orang tua, dengan batasan harus sesuai dengan firman Tuhan. Dalam Kolose 3:20 menuliskan, "Hai anak-anak, taatilah orang tuamu dalam segala hal, karena itulah yang indah di dalam Tuhan." Ayat tersebut memang mengatakan bahwa anak harus taat kepada orang tua 'dalam segala hal' Anak-anak harus memahami ayat ini dengan melihat ayat-ayat lain dalam Alkitab, yaitu pada saat orang tua memberikan perintah yang tidak sesuai dengan firman Tuhan atau dilarang oleh firman Tuhan, atau pun sebaliknya melarang untuk melakukan apa yang diperintahkan oleh Tuhan, maka dalam hal itu anak boleh tidak mentaati orang tua (Imeldawati, 2019). Dasar Alkitab dari pandangan ini adalah berdasar Kisah Para Rasul 5:29 dan Matius 10:37a yang menyatakan bahwa orang percaya harus 
lebih taat kepada Allah daripada kepada manusia dan harus lebih mengasihi Allah lebih dari semua manusia termasuk orang tua. Sedangkan Efesus 6:1 "Hai anakanak, taatilah orang tuamu di dalam Tuhan, karena haruslah demikian." Istilah "di dalam Tuhan" dalam ayat ini ditambahkan oleh Paulus berhubungan dengan Keluaran 20:12. Dan dalam kaitan dengan ini, Calvin (2000) memberikan komentar bahwa Paulus tidak hanya mendesak anak-anak untuk mentaati orang tua mereka, tetapi menambahkan batasan bahwa semua yang dilakukan untuk mentaati orang tua harus ada dalam koridor "di dalam Tuhan". Hal ini menunjukkan bahwa jika seorang ayah memerintahkan sesuatu yang tidak benar, ketaatan kepadanya dapat ditiadakan. (Budiman, 2019). Sepanda dengan Calvin, Stott menyatakan hal yang sama bahwa anak tidak harus mentaati orang tua mereka dalam segala hal secara mutlak tanpa perkecualian, tetapi dalam segala hal yang sesuai dengan junjunan tertinggi yaitu Tuhan Yesus Kristus. Hal lain yang perlu ditambahkan bahwa ketaatan anak kepada orang tua dibatasi pula oleh kondisi dari orang tua tersebut. Kalau ayah atau ibu mereka sudah lanjut usia dan pikun, sehingga menyuruh yang tidak semestinya, maka anak diperbolehkan tidak harus mentaati perintah mereka tersebut (Stott, 1986).

Kedua, Anak tidak boleh menghina, mencela, berkata kasar, mengutuki orang tua bahkan tidak boleh menginginkan sesuatu yang buruk terjadi terhadap mereka. Tertulis dalam Keluaran 21:17. Dosa mengutuki ayah dan ibu di sini dipertentangkan dengan kewajiban untuk menghormati mereka. Orang yang mencela ayah dan ibu mereka, atau yang mengharapkan sesuatu yang buruk terjadi atas mereka, yang menghina mereka, atau yang melontarkan katakata cemooh dan kasar terhadap mereka, melanggar hukum ini. Jika melontarkan kata "kafir" kepada sesama bisa dikenai hukuman yang begitu berat, apalagi jika berbuat demikian terhadap orang tua. Matius 15:4 "Sebab Allah berfirman: Hormatilah ayahmu dan ibumu; dan lagi: Siapa yang mengutuki ayahnya atau ibunya pasti dihukum mati" (Henry, n.d.).
Ketiga, Memelihara mereka pada saat mereka sudah tua atau pun pada saat mereka tidak bisa bekerja. Alkitab penuntun hidup berkelimpahan menuliskan; Menghormati ayah dan ibu akan berlanjut terus sampai kematian mereka. Salah satu cara untuk menghormati ayah dan ibu adalah dengan memperhatikan mereka pada saat-saat mereka memerlukan keuangan atau bila mereka sakit dan tidak mampu merawat diri sendiri. Merupakan kewajiban anakanak, jika orang tua mereka miskin dan kekurangan, maka anak harus meringankan beban orang tua dan menolongnya sesuai dengan kemampuannya. Jika tidak maka anak tersebut sudah berdosa dan melanggar perintah Tuhan. Jika mengutuki orang tua saja sudah patut dihukum mati, apalagi kalau sampai membuat orang tua mereka mati karena kelaparan (LAI, 2014).

\section{Janji Berkat bagi Yang Menghormati Orang Tua}

Tuhan berjanji akan memberikan berkat panjang umur dan baik keadaan kepada anak yang menghormati orang tuanya. Dalam Alkitab, ditulis dalam Keluaran 20:12: "Hormatilah ayahmu dan ibumu, supaya lanjut umurmu di tanah yang diberikan TUHAN, Allahmu, kepadamu." Ulangan 5:16: "Hormatilah ayahmu dan ibumu, seperti yang diperintahkan kepadamu oleh TUHAN, Allahmu, supaya lanjut umurmu dan baik keadaanmu di tanah yang diberikan TUHAN, Allahmu, kepadamu." Dan Efesus 6:2-3: "Hormatilah ayahmu dan ibumu" adalah suatu perintah yang penting, seperti yang nyata dari janji ini: "supaya kamu berbahagia dan panjang umurmu di bumi." Keluaran 20:12 dan Ulangan 5:15 kata pan-

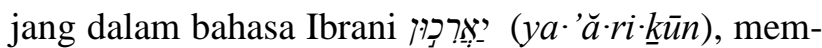
punyai arti; lanjut, lama, hidup lebih lama, panjang, menjadi panjang, sedangkan umur ditulis 铲 (yoma) mempunyai arti; hari-hari, umur, hari-hari umurmu, waktu, tahun umurmu. Sehingga kata panjang umur dalam Alkitab Terjemahan Baru mempunyai arti dalam bahasa aslinya yaitu tahun umurmu menjadi panjang. Sedangkan kata tanah dalam bahasa Ibrani

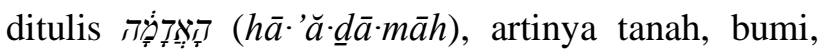
negeri. Dan kata berikan dalam bahasa Ibrani ditulis 
ذئ (nōttên), artinya; berikan, serahkan, karuniakan. Kata "baik" dalam Ulangan 5:16 ditulis dalam bahasa

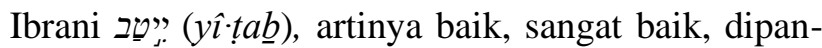
dang baik, berbahagia, mendatangkan keberuntungan. Dengan demikian arti dari kedua ayat ini adalah; Hormatilah ayah dan ibumu supaya tahun umurmu menjadi panjang, supaya kebahagiaan dan segala yang mendatangkan keberuntungan akan dikaruniakan TUHAN Allahmu kepadamu.

Berdasarkan ketiga ayat tersebut Tuhan akan memberikan kepada anak yang menghormati orang tuanya dengan panjang umur, baik keadaan, kebahagian dan segala yang mendatangkan keberuntungan. Mattew Henry mengatakan; janji menghormati orang tua adalah, supaya kamu berbahagia, dan panjang umur di bumi. Kemakmuran lahiriah dan umur panjang adalah berkat-berkat yang dijanjikan kepada orang-orang yang mentaati perintah ini. Anak-anak yang patuh sering kali dibalas dengan kemakmuran lahiriah. Memang tidak selalu demikian, ada juga anak-anak seperti itu yang mengalami banyak penderitaan dalam hidup ini. Tetapi ketaatan biasanya diberi balasan demikian, dan, jika tidak, digantikan dengan sesuatu yang lebih baik (Henry, n.d.).

\section{DAFTAR RUJUKAN}

Basuki, Y. E. (2014). Pertumbuhan Iman Yang Sempurna. Yogyakarta: Garudhawacha Online Book.

Budiman, K. S. (2019). Calvin dan Lima Pilar Institusi Sosial. Jurnal Teologi Dan Pelayanan: Veritas 10/02., 10(Lima pilaar institusi sosial).

Calvin, Y. (2000). Institutio. Jakarta: BPK Gunung Mulia.

Charis, E. (2016). Smart Parenting. Yogyakarta: Andi Offset.

Collier, R. (2018). Rahasia Sukses Sepanjang Zaman. Tangerang Selatan: Gemilang.

Dobson, J. (n.d.). Masalah Membesarkan Anak.

Eliman. (2017). Model Bimbingan Dalam Pendidikan agama Kristen Terhadap Pembentukan Moral

\section{KESIMPULAN}

Menghormati orang tua adalah sebuah sikap yang menunjukkan rasa hormat, yang wajib dilakukan seorang anak terhadap orang tua. Sikap tersebut bukan berdasarkan kesepakatan antara orang tua dan anak tetapi hukum Tuhan yang wajib dilakukan setiap anak. Allah mempunyai tujuan dengan hukum tersebut yaitu, agar anak mengenal Allah melalui teladan hidup orang tua, dan memahami maksud Allah dengan memelihara apa yang telah di tetapkan-Nya.

Sedangkan tindakan praktis yang dapat dilakukan anak sebagai wujud dari hormat kepada orang tua adalah Pertama, taat atau patuh. Hal ini dibatasi oleh keadaan orang tua yang tidak mengalami sakit kejiwaan atau kepikunan dan perintah mereka tidak melanggar hukum Tuhan. Kedua, tidak menghina, mencela, berkata kasar atau mengutuki orang tua. Ketiga, dengan cara merawat, memelihara dan membiayai hidup orang tua pada saat mereka sudah lanjut usia. Janji Tuhan kepada mereka yang menghormati orang tua adalah panjang umur, kebahagiaan dan memiliki keadaan baik berupa kemakmuran lahiriah dan rohani.

Anak Didik Usia 6-8 Tahun. Jurnal Teologi Dan Pelayanan Kristiani, 1 no. 2.

Frances, B. (2007). Inti Alkitab Untuk Para Pemula. Jakarta: BPK Gunung Mulia.

Henry, M. (n.d.). Bible commentary. Alkitab Sabda. Imeldawati, T. (2019). Makna Kata Taat dan Hormat dalam Efesus 6:1-3. KERUGMA: Jurnal Teologi Dan Pendidikan Agama Kristen, 1(2), 152-169.

LAI. (2014). Alkitab Penuntun Kehidupan. Malang. Leks, S. (2012). Tafsir Injil Matius. Yogyakarta: Kanisius.

Mary, E. (2020). Implikasi Ulangan 5:16 Dalam Pendidikan Keluarga. Didaché: Journal of Christian Education, Vol. 1, N, 14 1-1 52. 
Naibaho, D. (2018). Cara Orang tua Kristen Dalam Mendidik Anak. Jurnal Christian Humaniora, 2 no. 2.

Nggebu, S. (2016). Desain Allah bagi Anak dan Remaja. Bandung: Biji Sesawi.

Peterson, R. M. (2006). Kitab Keluaran. Jakarta: BPK Gunung Mulia.

Prince, D. (n.d.). Suami dan Ayah. Indonesia: Derek Prince Ministries Indonesia.

Putri, A. S. (2017). Dukungan Keluarga Terhadap Jemaat Lansia yang Melayani. EPIGRAPHE: Jurnal Teologi Dan Pelayanan Kristiani, 1 No. 2.

Ridenour, F. (2000). Dapatkah Alkitab Dipercaya. Jakarta: BPK Gunung Mulia.

Runturambi, R. (2019). Aspek Teologis dan Aplikatif Dasa Titah. Jurnal Teologi Berita Hidup, 1 No. 2.

Setiati, D. R. (2019). Peran Pendidikan Keluarga Dalam Pembentukan Sikap Sosial Dan Kemandirian Anak. Jurnal Teologi Dan Pendidikan Agama Kristen, 5 No. 1.

Simanjuntak, F. (2019). Diktat Etika kerja, bisnis dan kekayaan. Bandung: Sekolah Tinggi Teologi Kharisma Bandung.
Simanjuntak, J. (2017). Mendidik Anak Utuh, Menuai Keluarga Tangguh. Tangerang: Yayasan Pelikan.

Stamps, D. C. (1984). Catatan Penelitian dan Artikel Alkitab. In Alkitab Penuntun Hidup Berkelimpahan. Malang: Gandum Mas.

Stott, J. R. W. (1986). The Message of Ephesians. England: God's New Society.

Sulistiana, R. (2018). Kajian Hubungan Orang Tua dengan Anak Berdasarkan Efesus 6:1-4 di Gereja Gekisia Medan. Providensi: Jurnal Pendidikan Dan Teologi, 1 No. 1.

Tafonao, E. T. T. (2019). Pendidikan Anak dalam Keluarga Berdasarkan Kolose 3:21. Jurnal Teologi Dan Pendidikan Agama Kristen, 5 No. 1.

Wardani, F. L. R., \& Uyun, Z. (2017). "Ngajeni Wong Liyo"; Menghormati Orang yang Lebih Tua pada Remaja Etnis Jawa. Indigenous: Jurnal Ilmiah Psikologi. https://doi.org/10.23917/indigenous.v2i2.56 81 